\title{
Microscopic sperm head damage and abnormalities as heat stress indicators in Australian Merino rams (Ovis aries) in Northern Patagonia, Argentina
}

\section{Danos e anormalidades microscópicas das cabeças espermáticas como indicadores de estresse por calor em carneiros Merino Australiano (Ovis aries) da Patagônia Norte, Argentina}

\author{
María Fernanda LÓPEZ ARMENGOL ${ }^{1,2}$; Natalia RUBIO ${ }^{3}$; Guillermo Ariel SABINO'; \\ Nadia Soledad BÉRGAMO ${ }^{1,2}$; Valeria PELUFO ${ }^{1,2}$
}

\begin{abstract}
${ }^{1}$ Universidad Nacional del Comahue, Facultad de Ciencias Agrarias, Instituto de Biotecnología Agropecuaria del Comahue, Centro de Investigaciones en Toxicología Ambiental y Agrobiotecnología del Comahue, Cinco Saltos - Río Negro, Argentina ${ }^{2}$ Universidad Nacional del Comahue, Facultad de Ciencias Agrarias, Laboratorio de Teriogenología "Dr. Héctor H. Morello", Cinco Saltos - Río Negro, Argentina

${ }^{3}$ Universidad Nacional del Comahue, Facultad de Economía y Administración, Departamento de Estadística, Buenos Aires - Neuquén, Argentina
\end{abstract}

\begin{abstract}
In Northern Patagonia, the mating season starts on March 15th, when rams are submitted to summer temperatures. Exposure of rams to heat stress increases the prevalence of microscopic damage to spermatozoa, morphological abnormalities, and reductions in fertility. This study assesses the adaptive capabilities of six unshorn and six shorn Australian Merino rams, half of which were treated in a heat chamber for eight hours for five days, gradually reaching a temperature of up to $40{ }^{\circ} \mathrm{C}$. Microscopic damage, abnormalities and ultramicroscopic alterations of the plasma membrane and the acrosome of sperm head were analysed. There were significant differences in the percentage of tailless spermatozoa and proximal cytoplasmic droplets between post-treatment periods. Temperature primarily affected the shorn rams and the sperm heads during spermiogenesis. Submicroscopic alterations were observed when the plasma membrane was present in the anterior segment. These alterations can be intact, waved, or dilated. When the plasma membrane was absent, the acrosome might be intact, dilated, and waved. In addition, the outer acrosomal membrane may completely lose its contents or have a nude nucleus. The plasma membrane assumes a waved shape as a result of the effect of temperature on the epididymis. According to this study, the tailless head, proximal cytoplasmic droplets, and the ultramicroscopic categories studied were robust indicators of semen heat stress. After ten weeks, the sperm head recovered its normal shape. Unshorn rams are better adapted to summer heat stress than shorn ones. Microscopy and transmission electron microscopy alterations have been shown to be excellent indicators of thermal stress in Australian Merino rams and may be useful tools to help sheep farmers choose when to begin the mating season, which will vary depending on the environmental conditions of the summer.
\end{abstract}

Keywords: Proximal cytoplasmic droplet. Tailless spermatozoa. Ultramicroscopic sperm head damages. Heat stress. Shearing. Australian Merino.

\section{Resumo}

$\mathrm{Na}$ Patagônia Norte, os ovinos têm sua estação de acasalamento iniciada em 15 de março, portanto, ficam sujeitos às temperaturas do verão. A exposição de carneiros a estresse térmico aumenta a prevalência de danos microscópicos e anomalias morfológicas nos espermatozoides, que implica uma redução na fertilidade. Este trabalho avaliou a capacidade adaptativa de carneiros Merino Australiano com lã $(n=6)$ e tosquiados $(n=6)$ : metade ficou ao ar livre e outra metade foi mantida em uma câmara climática por oito horas, durante cinco dias, chegando gradualmente a uma temperatura máxima de $40^{\circ} \mathrm{C}$. Foram analisados danos microscópicos, anormalidades e alterações ultramicroscópicas da membrana plasmática e do acrossoma da cabeça dos espermatozoides. Os resultados microscópicos confirmaram a existência de diferença significativa na porcentagem de espermatozoides sem cauda e com gota citoplasmática proximal, entre os ejaculados pós-tratamento. A temperatura afetou os carneiros tosquiados, principalmente a cabeça de seus espermatozoides, durante a espermatogênese. Alterações submicroscópicas foram observados na membrana plasmática quando ela estava presente no segmento anterior: quando não intacta, ficava ondulada ou dilatada. Quando a membrana plasmática estava ausente, o acrossoma podia se apresentar ondulado ou dilatado. Além disso, sob efeito do calor, a membrana acrossomal externa pode perder completamente seu conteúdo ou apresentar núcleo desnudo. A 
membrana plasmática assume uma forma ondulada pelo efeito da temperatura no epidídimo. Depois de dez semanas, a cabeça dos espermatozoides recuperou sua forma normal. Como demonstrado neste estudo, a cabeça sem cauda, as gotas citoplasmáticas proximais e as categorias ultramicroscópicas estudadas são indicadores do efeito do estresse térmico no sêmen, e os carneiros com maior cobertura de lã se adaptam melhor ao estresse por calor. Alterações de microscopia e de microscopia eletrônica de transmissão têm se mostrado excelentes indicadores de estresse por calor em carneiros Merino Australiano e podem ser ferramentas úteis para ajudar criadores de ovelhas a escolher quando começar a época de acasalamento, o que irá variar de acordo com as condições ambientais do verão.

Palavras-chave: Gota citoplasmática proximal. Espermatozoide sem cauda. Danos ultramicroscópicos das cabeças espermáticas. Tosquia. Estresse por calor. Merino Australiano.

Correspondence to:

María Fernanda López Armengol

Universidad Nacional del Comahue, Facultad de Ciencias

Agrarias

Ruta $151, \mathrm{~km} 12$

CP 8303, Cinco Saltos, Río Negro, Argentina

e-mail: m.lopezarmengol@conicet.gov.ar

Received: $14 / 03 / 2016$

Approved: 01/12/2017

\section{Introduction}

Sheep production is the main agricultural activity in the Argentinean Patagonia (TEXEIRA et al., 2006). The mating season in Northern Patagonia begins on March 15 th, which is when rams are submitted to summer temperatures. In this area traditional flock shearing is conducted from November to December (late spring); thus, the rams spend the summer with fleece less than 1 inch in length. According to previous research sheep with 1 inch fleece are more comfortable than sheep with less wool because wool fibres dissipate heat more rapidly. Sheep with long wool were reported to be less sensitive to solar heating than newly shorn animals (CLOETE et al., 2000; PICCIONE et al., 2010).

In temperate regions, mean temperatures are expected to increase because of climate change. This increased temperature could have negative effects on agriculture, biodiversity, and human and animal health (SOLYMOSI et al., 2010). Optimal climatic conditions for sheep and goats are an air temperature of approximately $13^{\circ} \mathrm{C}$ to $20^{\circ} \mathrm{C}$, a wind velocity of 5 to $18 \mathrm{~km} / \mathrm{h}$, a relative humidity of $55 \%$ to $65 \%$, and a moderate level of sunshine (HAHN, 1985; ARAÚZ, 2009). However, these factors are interrelated (MARAI et al., 2008). Elevation of testicular temperature above normal levels is also known to induce alterations in spermatogenesis in mammals with scrotal testes (MIEUSSET et al., 1991; SETCHELL, 2006). A high percentage of rams may be sterile during the summer, especially under conditions of high humidity (MARAI et al., 2009).
Exposure of the ram scrotum to approximately $40^{\circ} \mathrm{C}$ for 1.5 to $2 \mathrm{~h}$ /day induced a sharp increase in the proportion of dead and tailless spermatozoa 14 to 50 days later (BRADEN; MATTNER, 1970). Damage to spermatozoa (e.g. tail abnormalities such as coiled tail, bent tail, and detached sperm heads and dead spermatozoa) and abnormalities (pyriform or pear-shaped cells, midpiece and acrosomal abnormalities) increased and fertility decreased in frozen semen (MIEUSSET et al., 1992). Tailless spermatozoa, normal detached sperm heads, and decapitated heads were observed in rams preceding scrotal insulation at a variable frequency (5\% to 30\%) (RATHORE, 1968; ROCHA et al., 2015). Rocha et al. (2015) also described the presence of $0.8 \%$ and $6 \%$ of distal cytoplasmic droplets before and 8 days after insulation, respectively.

In ewes mated to heat-stressed rams, failure to conceive was related more to a failure of fertilization than to embryonic mortality (BRADEN; MATTNER, 1970; CURTIS, 1983).

Different ram breeds require different times for the seminiferous epithelium to react and recover from the effects of environmental stress. In Bergamasca, Ile de France, Santa Ines, and Texel, recovery takes 10 weeks, and in Hampshire Down and Dorper breeds, recovery takes 11 weeks (CRUZ JÚNIOR et al., 2015).

Almost all tissues, cells, metabolic pathways, and biochemical reactions are affected by heat stress to a greater or lesser extent. There are some cell types that are especially thermally sensitive, such as mammalian male germ cells. Temperature has profound effects on the structural features of cell membranes, affecting higher orders of protein structure, protein-lipid interactions, and lipid-lipid interactions. Molecular structures that depend on weak interactions are easily changed by temperature. Such disturbances in the integrity of membrane function appear to be a fundamental cause of heat damage in organisms (SCHMIDT-NIELSEN, 1997; SALCES-ORTIZ et al., 2015).

Transmission electron microscopy (TEM) is the most accurate method for detecting submicroscopic damage 
and locating lesions after sample treatment (PLUMMER; WATSON, 1988; PIVKO et al., 2009; PELUFO et al., 2015). The assessment of spermatic plasma membrane and acrosome integrity by TEM allows ultrastructural change in sperm cell heads induced by heat stress to be characterized (WILLIAMSON, 1974).

The aim of this study was to analyse the type and frequency of microscopic and submicroscopic sperm alterations as heat stress indicators. Moreover, time of occurrence and sperm recovery of alterations were studied in order to identify the adaptive capabilities of unshorn and shorn rams exposed to a thermally stressful environment.

\section{Materials and Methods}

\section{Experimental location and climate}

The experiment was conducted for 16 weeks during the summer and fall, from January 24th to May 9th, 2011, at Facultad de Ciencias Agrarias (FCA), Universidad Nacional del Comahue, near Cinco Saltos (Province of Río Negro, Patagonia, Argentina). Meteorological data were collected daily from the thermo-hygrograph located $100 \mathrm{~m}$ from the open pens at FCA (38 $51^{\circ}$ 'S, $68^{\circ} 04^{\prime} \mathrm{W}, 281$ MASL) in the Neuquén River valley, which is surrounded by the Patagonian arid plateau. The region has an arid environment with an annual average rainfall of 186.24 $\mathrm{mm}$ (range $=90.7 \mathrm{~mm}-357.4 \mathrm{~mm})$ and annual average temperatures of $14.91{ }^{\circ} \mathrm{C}$ (range $=-1.4{ }^{\circ} \mathrm{C}-33.7^{\circ} \mathrm{C}$ ) (2001-2010 data). Climatological information from this location during the course of the study is presented in the work of López Armengol et al. (2015).

\section{Experimental animals}

Twelve healthy mature and unshorn Australian Merino rams were selected based on clinical examination of their reproductive system from a sheep farm located at Estancia Fortín Nogueyra "Los Corrales" (route 237, $\mathrm{km} \mathrm{1484}$, Province of Neuquén). The rams aged $31 / 2$ to 4 years, with live body weights ranging from 51 to $64 \mathrm{~kg}$ were previously acclimatized for three months. Shearing was performed to the whole body in six rams in November 2010. At the beginning of the heat chamber experience the fleece was 4.3 inches long in unshorn (Us) and 0.7 inches long in shorn (S). Food was offered once a day at $9 \mathrm{am}$ (1.350 g of Lucerne dry matter and oat energy supplement). Water was available ad libitum. The entire experiment was performed while ensuring that animal welfare conditions met the standards of the recommendations of the FCA, Universidad Nacional del Comahue.

\section{Experimental design}

After a period of three weeks considered to be a pre-treatment $(\mathrm{PT})$ period, the rams were randomly divided into two groups: one group $(n=6,3$ Us and 3S) experienced outdoor conditions, while the other group ( $\mathrm{n}=6,3 \mathrm{Us}$ and $3 \mathrm{~S}$ ) was kept indoors. The first experimental group served as the Control group (C) and was housed in open pens. The second group (Treated group, $\mathrm{T}$ ) was exposed to heat stress for 8 hours (from 9 am to $5 \mathrm{pm}$ ) over five days (February 14th-18th, 2011), followed by housing in open pens. Both groups were exposed to the same duration of natural photoperiods throughout the experiment. Three weeks before the experiment (January 24th, 2011), six rams in the $\mathrm{T}$ group were transferred to a place that had two spaces: one open space connected to another closed space (= heat chamber) where the rams kept circulating freely under ambient temperature conditions. During 5 days of treatment (February 14th-18th), the rams entered the heat chamber at $9 \mathrm{am}$, were fed, and experienced heat, and at $5 \mathrm{pm}$, they moved into an open space, where they spent the night. During the 8 hours that the rams remained in the heat chamber, they experienced a gradual increase in temperature from 25 to $40^{\circ} \mathrm{C}$, guaranteeing that they experienced $4 \mathrm{~h}$ of $40^{\circ} \mathrm{C}$ temperatures daily microclimatic heat chamber conditions were described by López Armengol et al. (2015). During the remaining 10 weeks, called the post-treatment period (February 19th to May 9th), all of the rams were kept in an opensided shelter-type barn. The 10 post-treatment weeks were analysed by grouping these 10 weeks into six periods: PT (ejaculates from three pre-treatments weeks); Period 1 (P1 = ejaculates from weeks 1 and 2; days 1 to 14 post-treatment); Period 2 (P2 = ejaculates from weeks 3 and 4; days 15 to 28 post-treatment); Period 3 (P3 = ejaculates from weeks 5 and 6; days 29 to 42 post-treatment); Period $4(\mathrm{P} 4=$ ejaculates from weeks 7 and 8 ; days 43 to 56 post-treatment) and Period 5 (P5 = ejaculates from weeks 10 to 12 ; days 64 to 84 post-treatment). As spermatogenesis proceeds via an orderly series of events, estimation of the approximate stage of germ cell development at various intervals before the time that sperm becomes available for 
ejaculation was possible. Based on the description of the ovine seminiferous epithelium cycle - approximately 61 days (MALAMA et al., 2013), these periods are consistent with the influence of heat on epididymis maturation (P1), seminiferous tubules (later and earlier spermiogenesis $=\mathrm{P} 2$; meiotic divisions $=\mathrm{P} 3$; mitotic phases of spermatogonia or spermatocytogenesis $=\mathrm{P} 4$ ), and recovery of the normal semen production period (P5) in treated rams (CARDOSO; QUEIROZ, 1988; JOHNSON et al., 2000; MALAMA et al., 2013).

\section{Semen characteristics}

The study was performed using 153 ejaculates: 36 pretreatments and 117 post-treatments. Ejaculates were collected at 9 am weekly; the first semen collections after treatment were collected on February 23rd (C) and February 28th (T) by means of an electroejaculator for sheep and goats (Bailey, Western Instrumental Company, Denver, CO, USA). One ejaculate was collected each time per ram.

Microscopic (MO) sperm damages and abnormalities were recorded from at least 100 spermatozoa from 153 ejaculates and expressed as a proportion of the total sperm that were analysed. Seminal quality parameters were evaluated in vitro by collecting the following data: volume, mass motility, sperm concentration, total number of spermatozoa, individual sperm cell motility (IM), vigour, viability with eosin-nigrosin staining, acrosome integrity by phase contrast microscopy, and plasma membrane functional integrity by hypoosmotic swelling test (Host) (JEYENDRAN et al., 1984; AISEN, 2004).

\section{Transmission electron microscopy}

Eight samples of heterospermic fresh semen from each ram during week 2 (P1) and from rams during weeks 4 (P2) and 10 (P5) post-treatment were evaluated. TEM preparation and the criteria used for morphological evaluation of semen were based on the method of López Armengol et al. (2012). Six categories were analysed, including the status of the plasma membrane (PM) and acrosome (Acr) on 824 profiles of sperm heads. The categories considered were the following: (i) Intact PM, intact Acr (Figure 1A); (ii) Dilated PM, intact Acr (Figure 1B); (iii) Waved PM, intact Acr (Figure 1C); (iv) PM absence, intact Acr (Figure 1D); (v) PM absence, Acr showing very dilated outer acrosomal membrane with complete loss of content (Figure 1E) and (vi) PM and Acr absence, nude nucleus (Figure 1F).

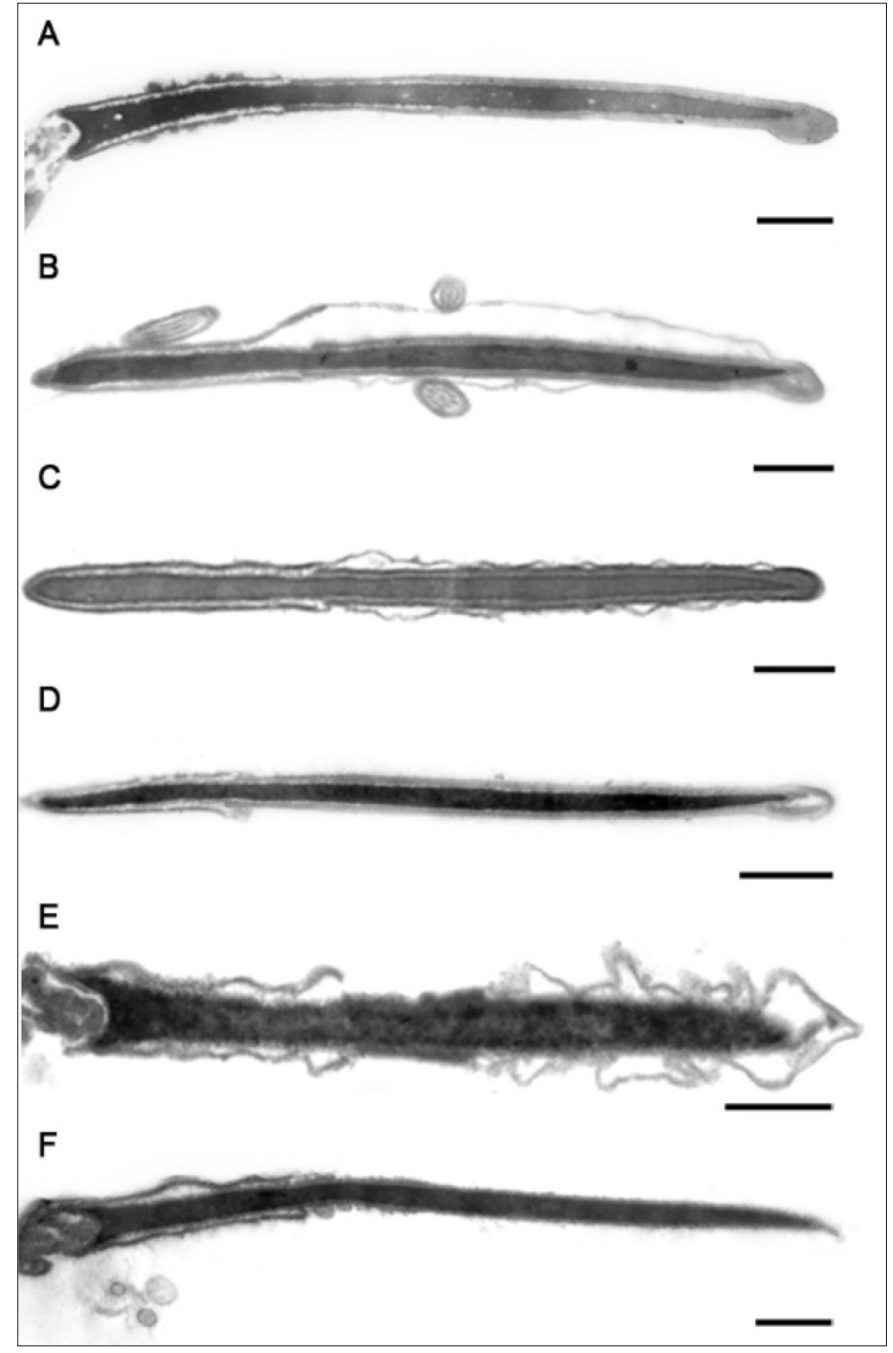

Figure 1 - Ultramorphology of ram spermatozoa. Longitudinal sections of sperm heads showing the following: A. Intact plasma membrane (PM) and acrosome (Acr). B. Dilated PM and intact Acr. C. Waved PM and intact Acr. D. PM absence and intact Acr. E. PM absence, Acr showing very dilated and waved outer acrosomal membrane with complete loss of content. F. PM and Acr absence, nude nucleus. Scale bar $=1 \mu \mathrm{m}$

\section{Estimation of heat stress severity}

A method for estimating the severity of heat stress was proposed using both ambient daily maximum temperature and relative humidity, termed the maximum temperature humidity index $\left(\mathrm{THI}_{\max }\right)$. The equation used was the following:

$\mathrm{THI}_{\text {max }}=\mathrm{Tdb}_{\text {max }}-\left\{(0.31-0.31 \mathrm{RH})\left(\mathrm{Tdb}_{\text {max }}-14.4\right)\right\}$ (MARAI et al., 2001; MARAI et al., 2009; MALAMA et al., 2013) where $\mathrm{Tdb}_{\text {max }}$ is the daily maximum dry bulb temperature $\left({ }^{\circ} \mathrm{C}\right)$ and $\mathrm{RH}$ is the relative humidity (RH \%)/100. Marai et al. (2009) used this index in a study of Egyptian Suffolk rams and the classification of the scores obtained was the following: $<22.2=$ absence of heat stress; 22.2 to $<23.3=$ moderate heat stress; 23.3 to $<25.6=$ severe heat stress; $>5.6=$ extreme severe heat stress. 
As a measure of heat load received by the epididymis and testes during spermatogenesis, climatic factors were expressed as a mean $\mathrm{THI}_{\max } 61$ days before each weekly ejaculation day (day 0 ). The mean $\mathrm{THI}_{\max }$ per period (PT and 1 to 5) was calculated by averaging climatic factors per week (e.g. for P1, averaging weeks 1 and 2).

\section{Statistical analyses}

\section{MO damages}

A first descriptive analysis was performed from a database that consisted of percentages of MO damages and midpiece abnormalities in 153 ejaculates from control/ unshorn $(\mathrm{n}=39)$, control/shorn $(\mathrm{n}=36)$, treated/unshorn $(\mathrm{n}=39)$, and treated/shorn $(\mathrm{n}=39)$ rams grouped in the six periods (PT and P1 to P5). The $\chi^{2}$ test was used to compare the frequencies of tailless spermatozoa and proximal cytoplasmic droplets of unshorn/shorn for each period (P1 to P5). In all cases, the level of significance used was $p=1 \%$.

To analyse the functionality of the sperm, MO damages and abnormalities and TEM categories, Pearson's correlation was used on data from a database of seminal quality parameters and the alterations recorded from 67 ejaculates.

\section{TEM damages}

Multiple correspondence analysis was used from a database which includes the percentages of TEM categories in control and ejaculates of treated rams from week 2 (Period 1) and ejaculates of treated rams from week $4($ Period 2$)$ and week 10 (Period 5) (NENADIĆ; GREENACRE, 2007). To this database mean climatic factors and seminal quality parameters for all ejaculates were added in order to determine the functionality of the submicroscopic damages that occurred on fresh semen. Pearson's correlation was calculated on both sets of data. In all cases, the level of significance used was $p=5 \%$.

\section{Results}

\section{Damages and abnormalities observed with MO}

The semen samples had mostly cells with proximal cytoplasmic droplets and tailless spermatozoa. No alteration was observed in pre-treatment ejaculates. In addition, changes were observed in the ellipticity of the sperm heads in treated shorn rams on Days 43 to 49 after treatment (LÓPEZ ARMENGOL et al., 2015).

Figure 2 illustrates the percentages of both types of alterations over the PT and five post-treatment
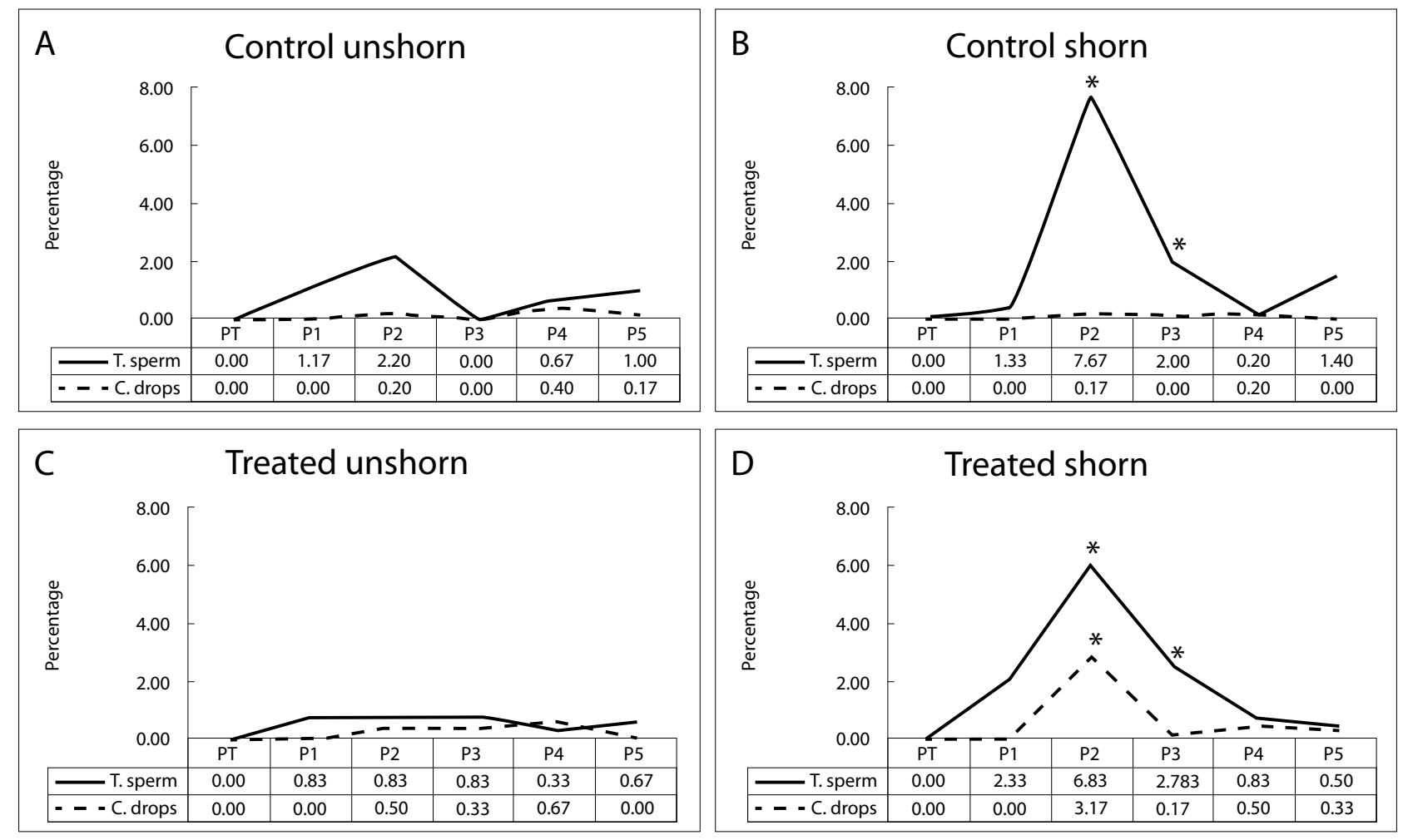

Figure 2 - Percentage of tailless spermatozoa and proximal cytoplasmic droplets in ram ejaculate during six periods. A. Control unshorn rams. B. Control shorn rams. C. Treated unshorn rams. D. Treated shorn rams. ${ }^{*}=$ indicate highly significant differences $(\mathrm{p}<0.01)$. Abbreviations. $\mathrm{PT}=$ pre-treatment period. $\mathrm{P} 1=$ Period 1 (heat influenced on epididymal maturation); P2 = Period 2 (heat influenced on seminiferous tubules, later and earlier spermatogenesis); P3 = Period 3 (heat influence on meiotic divisions); $\mathrm{P} 4=$ Period 4 (heat influenced on phase of mitoses of spermatogonia) and P5= Period 5 (recovery of normal semen production); T.sperm = tailless spermatozoa; C. drops = proximal cytoplasmic droplets 
periods studied. Tailless spermatozoa appeared in ejaculates in $\mathrm{P} 1$, most often in the treated shorn rams (2.33\%), and reached a peak in P2 in shorn rams ( $7.67 \%$ in control, and $6.83 \%$ in treated rams). Tailless spermatozoa were observed at different percentages along the periods and under different ram conditions. Highly significant differences ( $\chi^{2}$ test) were observed in shorn rams, both in control and treated rams in P2 and P3 (Figure 2B and D).

The highest percentages of proximal cytoplasmic droplets were present in P2 in treated rams: $0.50 \%$ in unshorn rams and $3.17 \%$ in shorn rams. Highly significant differences were observed only in treated shorn rams in P2 (Figure 2D).

The mean $\mathrm{THI}_{\max }$ registered for the ambient conditions for control and treated rams demonstrated that for the periods analysed (PT and P1 to P5) heat stress changed from severe $(\mathrm{PT}=25.80)$ to absent $(\mathrm{P} 5=21.82)$ to extremely severe $(\mathrm{P} 1-\mathrm{P} 3$, THI $>25.6)$. The highest values were 26.37 and 26.92 for control climatic conditions and 27.04 and 27.17 for treatment conditions in periods 1 and 2. Thus, ejaculates during these periods suffered extreme severe heat stress (Figure 3).

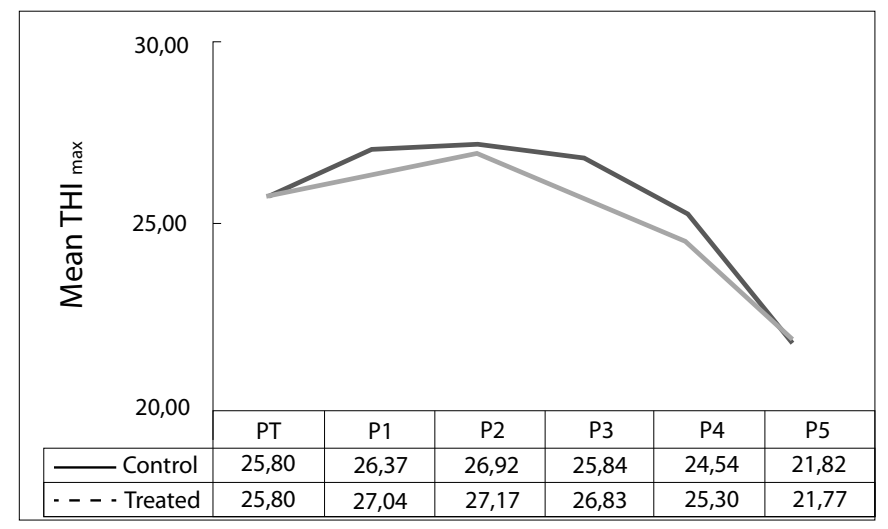

Figure 3 - Mean THI max $_{\text {for }}$ the six periods studied for control and treated rams. Mean $\mathrm{THI}_{\max }$ was calculated from the daily $\mathrm{THI}_{\max } 61$ days before each weekly ejaculation (day 0). Abbreviations. $\mathrm{PT}=$ pretreatment period. $\mathrm{P} 1$ to $\mathrm{P} 5=$ Period 1 to Period 5

\section{Types of damages observed with TEM}

The percentages of TEM categories analysed in periods 1,2 , and 5 are shown in Table 1 . It is noticeable that $\mathrm{P} 1$ was characterized by having a higher percentage of waved PMs for all rams (Figure 1C; between $47 \%$ to $92 \%$ ), that $\mathrm{P} 2$ had the highest dilated PM percentagein treated unshorn and shorn rams (Figure 1B; between $72 \%$ to $76 \%$ ), and that P5 had the highest normal spermatozoa (Figure 1A; 12\%) in treated unshorn rams.

Table 1 - Percentage of ultramicroscopic damage categories of different rams' conditions spermatozoa, along different periods of spermatogenic cycle

\begin{tabular}{lccccccc}
\hline Period & $\begin{array}{c}\text { Rams } \\
\text { conditions }\end{array}$ & $\begin{array}{c}\text { \% Intact PM, } \\
\text { intact Acr }\end{array}$ & $\begin{array}{c}\text { \% Waved PM, } \\
\text { intact Acr }\end{array}$ & $\begin{array}{c}\text { \% Dilated PM, } \\
\text { intact Acr }\end{array}$ & $\begin{array}{c}\text { \% PM absence, } \\
\text { intact Acr }\end{array}$ & $\begin{array}{c}\text { \% PM absence, } \\
\text { outer acrosomal } \\
\text { altered,content } \\
\text { absence }\end{array}$ & $\begin{array}{c}\text { \% PM and Acr } \\
\text { absence,nude } \\
\text { nucleus }\end{array}$ \\
\hline P1 & CUs & 6 & 78 & 3 & 0 & 13 & 11 \\
\\
\end{tabular}

Abbeviations: P1 = Period 1, heat influence on epididymal maturation; P2 = Period 2, heat influenced on seminiferous tubules, later and earlier spermatogenesis; $\mathrm{P} 5=$ Period 5, recovery of the normal semen production period; CUs = control unshorn; CS = control shorn; Tus = treated unshorn; TS = treated shorn; PM = plasma membrane; Acr = acrosome

Figure 4 illustrates the results of the multiple correspondence analyses of submicroscopic damages observed in sperm heads in periods 1,2 , and 5 , in which closer relationships between periods and TEM categories were observed. During P1, both unshorn rams (control and treated) had waved PM. The treated shorn rams in P1 were located between the waved PM and the absence of PM with acrosomes without content (Figure 1E). Treated rams are linked to dilated PM in P2; the shorn rams exhibited dilated PM to a greater degree than unshorn rams. In P5, the treated shorn rams were associated with PM absence and acrosomes without content. 


\section{MO and TEM damages and abnormalities and semen characteristics}

Tailless spermatozoa were inversely correlated with IM (-0.35). No significant differences were observed between proximal cytoplasmic droplets and seminal quality parameters.

The waved PM with intact Acr category was positively correlated with viability with eosin-nigrosin staining (0.87), intact acrosome (0.82), and Host (0.83). The dilated PM with intact Acr category was inversely correlated with eosinnigrosin staining (-0.86), intact acrosome (-0.95), and Host $(-0.82)$. PM and Acr absence and the presence of nude nuclei (Figure $1 \mathrm{~F}$ ) were inversely correlated with IM (-0.83).

\section{Discussion}

$\mathrm{MO}$ alterations were not observed in pre-treatment ejaculates. In post-treatment periods (P1 to P5), different types and percentages of $\mathrm{MO}$ alterations were recorded in treated rams due to the heat chamber conditions and in control rams due to the summer heat (Figure 2 and Figure 3).

Semen alterations that were observed primarily included MO damages, such as tailless spermatozoa, and, less often, abnormalities such as proximal cytoplasmic droplets (Figure 2).

The percentage of tailless spermatozoa observed (7.67\% in control shorn rams) was lower than that cited by Rathore (1968) of $13 \%$ and $30 \%$ for Merino rams heated during 2 and 4 days (8h daily), respectively. Rocha et al. (2015) recorded $5 \%$ in ejaculates preceding scrotal insulation and $12.5 \%$ in ejaculates 8 days after. One explanation of this inconsistency may be the heating technique that was used. In our study, entire animals were exposed to a heated environment; however, in the work of Rocha et al. (2015), the scrota of rams were insulates.

Tailless spermatozoa in the ejaculates of all rams were observed at different frequencies along the periods (Figure 2). These differences can be explained by the effect of heat on epididymal maturation in $\mathrm{P} 1$, and on seminiferous epithelium cycle in P2 to P4. The highly significant differences in shorn rams (control and treated) in P2 and P3 demonstrated that effect of temperature was higher (Figure 2B and D). P5 (week 10 to 12 post-treatment) can be considered the period when recovery is complete and when semen production is normal for all rams. This finding demonstrates the ability of the seminiferous epithelium to react to the effects of environmental factors. These results are consistent with those of Braden and Mattner (1970), who described an increased proportion of dead and tailless spermatozoa between days 14 and 50 as a result of the effects of scrotal heating in rams. Rocha et al. (2015) also reported a $12.5 \%$ death rate in ejaculates 8 days after scrotal heating, which is similar to the percentage observed in this study.

A plausible explanation for the occurrence of tailless spermatozoa was proposed by Bhattacharyya et al. (2010). They proposed that the neck region of spermatozoa is vulnerable and fragile. Thus, the sperm head can become detached from the midpiece when motility is initiated, which occurs at the base of the sperm head. Spermatozoa acquire motility between the head and tail of the epididymis; thus, the scope for detachment of the head of the spermatozoa would be greatest in the lower head or body region. Our results demonstrated that the neck region of spermatozoa during the spermiogenesis was affected by natural and artificial heating (mean temperature $=30.70^{\circ} \mathrm{C}$; mean humidity $=29.14$ THI $\left._{\text {max }}=27.17\right)$. As changes occur at the level of the seminiferous tubules, they primarily involve sperm abnormalities based on classification by their site of origin (BRIZ et al., 1996). This result is consistent with the results of Branden and Mattner (1970), who stated that heating results in considerable damage to spermatozoa developing in the testes, and Setchell (2006), who stated more precisely that the primary spermatocytes and early spermatids are the most heat-susceptible cells in mammalian testes.

Decreases in the percentage of motile, progressive, and rapid sperm were reported by Arman et al. (2006) in the ejaculates of adult Merino rams after intermittent scrotal insulation. According to our study, IM was inversely correlated with the frequency of tailless sperm cells in ejaculates, which may be result of the existence of tailless sperm cells.

An increased percentage of proximal cytoplasmic droplets was observed in treated shorn rams (3.17\%), which coincided with later and earlier stages in spermiogenesis (P2) (Figure 2). Briz et al. (1996) stated about sperm malformations on the epididymis ducts of boars that sperm cells with proximal cytoplasmic droplets do not originate in the epididymis. Rocha et al. (2015) reported $0.8 \%$ in ejaculates preceding scrotal insulation and $6 \%$ in ejaculates 8 days after treatment. One explanation for these differences in the percentages observed may be the heating technique used. Some studies have exposed entire animals 
to a heated environment, while other studies have only insulated the scrota of the rams. The percentage of sperm malformations is most often found to be lower when entire animals are heated rather than when only the scrotum is heated. Pesch and Bergmann (2006) reported that proximal droplets have a tremendous impact on fertility and are considered as major defects.

The submicroscopic head sperm alterations observed demonstrated that the sperm heads of all of the rams had waved PMs in P1. This alteration was produced by the artificial and natural climatic conditions experienced by the epididymis (Table 1, Figure 4). The presence of dilated $\mathrm{PM}$ in the sperm heads in treated rams in P2 may be due to the effect of heat on spermiogenesis (Table 1, Figure 4).
One explanation for these ultrastructural alterations in the sperm head PM (waved, dilated, or absent) could be that, as stated by Knuth-Nilsen (1997), temperature critically affects the membrane structure of the epididymis (PM waved) and testis (PM dilated and absence). This possibility is important and provides a potential explanation for a broad range of alterations. Temperature has profound effects on interactions by affecting higher orders of protein structure, protein-lipid interactions and lipid-lipid interactions. Molecular structures that depend on weak interactions can be easily changed by temperature. In the same way, heat affects the outer acrosomal membrane, and this was manifested during P1 and P2 as dilated and waved PM.

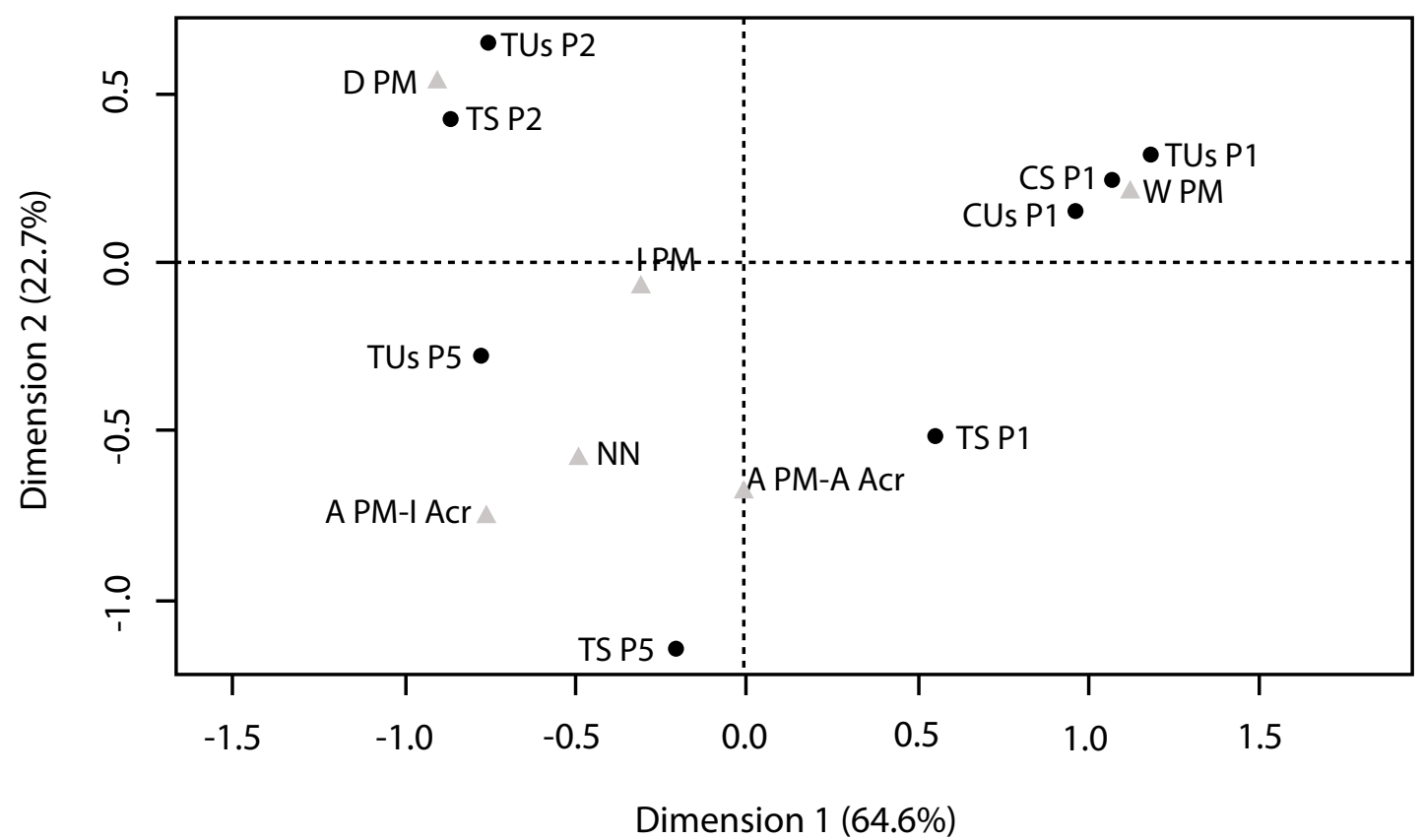

Figure 4 - Multiple correspondence analyses plot. Relationships between ram condition in period 1, 2, and 5 and TEM categories studied in sperm heads are displayed. Abbreviations. I PM = Intact PM, intact acrosome (Acr). W PM = Waved PM, intact Acr. D PM = Dilated PM, intact Acr. A PM-I Acr = Absent PM, intact Acr. A PM-A Acr = Absent PM, Acr showing very dilated outer acrosomal membrane with complete loss of content. $\mathrm{NN}=$ nude nucleus

Period 5 can be considered to be a semen recovery period. Evidence of this was in the percentage of PM and intact Acr in the sperm heads of treated rams when compared to the percentages of those observed in P1 and P2 (Table 1). In addition, unshorn rams recovered faster than shorn ones, as shown by the higher percentage of sperm heads with PM and intact Acr (12\%) and the close relationship to this category in the correspondence analysis (Figure 4). Treated shorn rams from P5 showed waved PM (6\%) (Table 1) and a higher percentage of Acr without content (61\%) and with nude nuclei (8\%) (Table 1).
Ultrastructural alterations observed in this study were also observed by Williamson (1974) in Saxon Merino rams when their scrota were locally heated. In this study we did not observe sperm heads to have twisted and distorted acrosomes away from the nucleus.

Waved PM were functionally associated with cell viability, as indicated by the significant and direct correlation between this category and eosin-nigrosin staining, intact acrosome, and Host. Conversely, dilated PM was not functionally associated with cell viability. IM decreased when the percentage of PM, Acr absence, and nude nuclei increased. 
Tailless spermatozoa and proximal cytoplasmic droplets resulted from the effect of temperature on testes and, more precisely, during the spermiogenesis phase. Waved PM resulted from the effect of temperature on the epididymis, whereas dilated PM resulted from the effect of temperature on the testis. From the correlations with sperm quality parameters, we demonstrated that waved PM may be functionally associated with cell viability, unlike dilated PM.

In conclusion, the study of MO and TEM alterations demonstrated that all rams were affected not only by the heat treatment but also by the summer temperatures. The effect of temperature on semen quality was higher in shorn rams than in unshorn rams. Based on the higher percentage of tailless spermatozoa, proximal cytoplasmic droplets, submicroscopic damages, and higher proportions of elliptical heads (LÓPEZ ARMENGOL et al., 2015). Our findings are consistent with data from other studies, which have stated that wool protects sheep from extreme heat and extreme cold. A thick fleece is mostly protective against temperature changes because of its insulating properties. According to this research, sheep with 1 inch fleece are more comfortable than sheep with less wool, as wool fibres dissipate heat more rapidly. Sheep with long wool were

\section{References}

AISEN, E. G. Reproducción ovina y caprina. Buenos Aires: Intermédica, 2004.

ARAÚZ, E. E. Importancia del microambiente para el desempeño fisiológico y efectos negativos del estrés calórico sobre la capacidad fisiológica y de producción en los caprinos y ovinos. Engormix, 2009. Available from: <https://goo.gl/cuQBah>. Viewed: 26 Feb. 2018.

ARMAN, C.; QUINTANA CASARES, P. I.; SANCHEZPARTIDA, L. G.; SETCHELL, B. P. Ram sperm motility after intermittent scrotal insulation evaluated by manual and computer-assisted methods. Asian Journal of Andrology, v. 8, n. 4, p. 411-418, 2006. doi: 10.1111/j.1745-7262.2006.00145.x.

BHATTACHARYYA, H. K.; BUJARBARUAH, K. M.; GOSWAMI, B. K.; BISWAS, R. K.; KHAN, I. Changes in Mithun (Bos frontalis) spermatozoa during reportedly less sensitive to solar heating than newly shorn animals (PARER, 1963; JOHNSON, 1991). Piccione et al. (2010) confirmed that shearing induces adaptive responses in organisms.

Also, these results demonstrated that in Australian Merino from Northern Patagonia, at least 10 weeks were necessary to recover from heat stress and restore normal semen production.

The semen quality evaluation at the end of summer is a very important issue especially to the sheep farmers who want to place the first lambs in the market. MO and TEM alterations and sperm head ellipticity (LÓPEZ ARMENGOL et al., 2015) have been shown to be excellent indicators of thermal stress in Australian Merino rams and may be useful tools to help sheep farmers choose when to begin the mating season, which will vary depending on the environmental conditions of the summer.

\section{Acknowledgements}

This work was supported by Grant 04/A 109 and 04/A 126 from the Universidad Nacional del Comahue and was performed under a specific agreement between the Facultad de Ciencias Agrarias de la Universidad Nacional del Comahue and the Facultad de Ciencias Veterinarias de la Universidad Nacional de La Plata.

epididymal passage. Journal of the South African Veterinary Association, v. 81, n. 2, p. 80-81, 2010. doi: $10.4102 /$ jsava.v81i.

BRADEN, A. W. H.; MATTNER, P. E. The effects of scrotal heating in the ram on semen characteristics, fecundity, and embryonic mortality. Crop and Pasture Science, v. 1, n. 3, p. 509-518, 1970. doi: 10.1071/ AR9700509.

BRIZ, M. D.; BONET, S.; PINART, B.; CAMPS, R. Sperm malformations throughout the boar epididymal duct. Animal Reproduction Science, v. 43, n. 4, p. 221-239, 1996. doi: 10.1016/0378-4320(96)01470-4.

CARDOSO, F. M.; QUEIROZ, G. F. Duration of the cycle of the seminiferous epithelium and daily sperm production of Brazilian hairy rams. Animal 
Reproduction Science, v. 17, n. 1-2, p. 77-84, 1988. doi: 10.1016/0378-4320(88)90047-4.

ClOETE, S. W. P.; MULlER, C. J. C.; DURAND, A. The effects of shade and shearing date on the production of Merino sheep in the Swartland region of South Africa. South African Journal of Animal Science, v. 30, n. 3, p. 164-171, 2000. doi: 10.4314/sajas.v30i3.3848.

CRUZ JÚNIOR, C. A.; LUCCI, C. M.; PERIPOLLI, V.; SILVA, A.F.; MENEZES, A. M.; MORAIS, S. R. L.;ARAÚJO, M. S.; RIBEIRO, L. M. C. S.; MATTOS, R. C.; MCMANUS, C. Effects of testicle insulation on seminal traits in rams: preliminary study. Small Ruminant Research, v. 130, p. 157-165, 2015. doi: 10.1016/j.smallrumres.2015.06.014.

CURTIS, S. E. Environmental management in animal agriculture. Ames: Iowa State University, 1983.

HAHN, G. L. Management and housing of farm animals in hot environments. In: YOUSEF, M. K. (Ed.). Stress physiology in livestock. Boca Raton: CRC, 1985. p. 151-174.

JEYENDRAN, R. S.; VAN DER VEN, H. H.; PEREZPELAEZ, M.; CRABO, B. G.; ZANEVELD, L. J. D. Development of an assay to assess the functional integrity of the human sperm membrane and its relationship to other semen characteristics. Journal of Reproduction and Fertility, v. 70, n. 1, p. 219-228, 1984. doi: 10.1530/jrf.0.0700219.

JOHNSON, K. G. Body temperatures and respiratory rates of free ranging Merino sheep in and out of shade during Summer. Crop and Pasture Science, v. 42, n. 8, p. 1347-1357, 1991. doi: 10.1071/AR9911347.

JOHNSON, L.; VARNER, D. D.; ROBERTS, M. E.; SMITH, T. L.; KEILLOR, G. E.; SCRUTCHFIELD, W. L. Efficiency of spermatogenesis: a comparative approach. Animal Reproduction Sciences, v. 60-61, p. 471-480, 2000. doi: 10.1016/S0378-4320(00)00108-1.

LÓPEZ ARMENGOL, M. F.; JURADO, S. B.; PELUFO, V.; AISEN, E. G. A quantitative ultramorphological approach for systematic assessment of sperm head regions: an example in rams. Cryobiology, v. 64, n. 3, p. 223-234, 2012. doi: 10.1016/j.cryobiol.2012.02.004.
LÓPEZ ARMENGOL, M. F.; SABINO, G. A.; FORQUERA, J. C.; DE LA CASA, A.; AISEN, E. G. Sperm head ellipticity as a heat stress indicator in Australian Merino rams (Ovis aries) in Northern Patagonia, Argentina. Theriogenology, v. 83, n. 4, p. 553-559, 2015. doi: 10.1016/j.theriogenology.2014.10.020.

MALAMA, E.; BOLLWEIN, H; TAITZOGLOU, I. A.; THEODOSIOU, T.; BOSCOS, C. M.; KIOSSIS, E. Chromatin integrity of ram spermatozoa: relationships to annual fluctuations of scrotal surface temperature and temperature-humidity index. Theriogenology, v. 80, n. 5, p. 533-541, 2013. doi: 10.1016/j.theriogenology.2013.05.019.

MARAI, I. F. M.; AYYAT, M.S.; ABD EL-MONEM, U. M. Growth performance and reproductive traits at first parity of New Zealand White female rabbits as affected by heat stress and its alleviation, under Egyptian conditions. Tropical Animal Health and Production, v. 33, n. 6, p. 451-462, 2001. doi: 10.1023/A:1012772311177.

MARAI, I. F. M.; EL-DARAWANYA, A. A.; FADIEL, A.; ABDEL-HAFEZB, M. A. M. Reproductive performance traits as affected by heat stress and its alleviation in sheep. Tropical and Subtropical Agroecosystems, v. 8, n. 3, p. 209-234, 2008. Available from: <https://goo.gl/cbfa3Y>. Viewed:26 Feb. 2018.

MARAI, I. F. M.; EL-DARAWANY, A. A.; ISMAIL, E. A.; ABDEL-HAFEZ, M. A. M. Reproductive and physiological traits of Egyptian Suffolk rams as affected by selenium dietary supplementation and housing heat radiation effects during winter of the sub-tropical environment of Egypt. Arch Tierzucht, v. 52, n. 4, p. 402-409, 2009. doi: 10.5194/aab-52-402-2009.

MIEUSSET, R.; QUINTANA CASARES, P. I.; SANCHEZPARTIDA, L. G.; SOWERBUTTS, S. F.; ZUPP, J. L.; SETCHELL, B. P. Effects of heating the testes and epididymides of rams by scrotal insulation on fertility and embryonic mortality in ewes inseminated with frozen semen. Journal of Reproduction and Fertility, v. 94, n. 2, p. 337-343, 1992. doi: 10.1530/jrf.0.0940337.

MIEUSSET, R.; QUINTANA CASARES, P. I.; SANCHEZPARTIDA, L. G.; SOWERBUTTS, S. F.; ZUPP, J. L.; SETCHELL, B. P. The effects of moderate heating of the testes and epididymides of rams by scrotal insulation on body temperature, respiratory rate, spermatozoa output 
and motility, and on fertility and embryonic survival in ewes inseminated with frozen semen. Annals of the New York Academy of Sciences, v. 637, n. 1, p. 445-458, 1991. doi: 10.1111/j.1749-6632.1991.tb27329.x.

NENADIĆ, O.; GREENACRE. M. Correspondence analysis in $\mathrm{R}$, with two- and three-dimensional graphics: the CA package. Journal of Statistical Software, v. 20, n. 3, p. 1-13, 2007. doi: 10.18637/jss.v020.i03.

PARER, J. T. Wool length and radiant heating effects in sheep. The Journal of Agricultural Science, v. 60, n. 1, p. 141-144, 1963. doi: 10.1017/S0021859600015926.

PELUFO, V.; LÓPEZ ARMENGOL, M. F.; MALCOTTI, V.; VENTURINO, A.; AISEN, E. G. Effects of glycerol and sugar mixing temperature on the morphologic and functional integrity of cryopreserved ram sperm. Theriogenology, v. 83, n. 1, p. 144-151, 2015. doi: 10.1016/j.theriogenology.2014.09.007.

PESCH, S.; BERGMANN, M. Structure of mammalian spermatozoa in respect to viability, fertility and cryopreservation. Micron, v. 37, n. 7, p. 597-612, 2006. doi: 10.1016/j.micron.2006.02.006.

PICCIONE, G.; CASElla, S.; ALBERGHINA, D.; ZUMBO, A.; PENNISI, P. Impact of shearing on body weight and serum total proteins in ewes. Spanish Journal of Agricultural Research, v. 8, n. 2, p. 342-346, 2010. doi: 10.5424/sjar/2010082-1217.

PIVKO, J.; MAKAREVICH, A. V.; KUBOVIČOVA, E.; RIHA, L.; SIROTKIN, A. V.; MATEJAŠAKOVÁ, E. Ultrastructural alterations in sperm heads under influence of several implementors to ram semen. Slovak Journal Animal Sciences, v. 42, n. 4, p. 149-154, 2009. Availablefrom: <https://goo.gl/R5EnfL>. Viewed: 26 Feb. 2018.

PLUMMER, J. M.; WATSON, P. F. The quantitative ultrastructural assessment of head membrane damage in boar spermatozoa subjected to varying degrees of cold shock. Animal Reproduction Sciences, v. 16, n. 3-4, p. 265-275, 1988. doi: 10.1016/0378-4320(88)90020-6.

RATHORE, A. K. Effects of high temperature on sperm morphology and subsequent fertility in Merino sheep.
Proceedings of the Australian Society of Animal Production, v. 7, p. 270-274, 1968. Available from: <https://goo.gl/XYKjKq>. Viewed: 26 Feb. 2018.

ROCHA, D. R.; MARTINS, J. A. M.; VANTILBURG, M. F.; OLIVEIRA, R. V.; MORENO, F. B.; MONTEIROMOREIRA, A. C. O.; MOREIRA, R. A.; ARAÚJO, A. A.; MOURA, A, A. Effect of increased testicular temperature on seminal plasma proteome of the ram. Theriogenology, v. 84, n. 8, p. 1291-1305, 2015. doi: 10.1016/j.theriogenology.2015.07.008.

SALCES-ORTIZ, J.; RAMÓN, M.; GONZÁLEZ, C.; PÉREZ-GUZMÁN, M. D.; GARDE, J. J.; GARCÍAÁlVAREZ, O.; MAROTO-MORALES, A.; CALVO, J. H.; SERRANO, M. M. Differences in the ovine HSP90AA1 gene expression rates caused by two linked polymorphisms at its promoter affect rams sperm DNA fragmentation under environmental heat stress conditions. Plos One, v. 10, n. 2, 2015. doi: 10.1371/ journal.pone.0116360.

SCHMIDT-NIELSEN, K. Animal physiology: adaptation and environment. 5. ed. New York: Cambridge University, 1997.

SETCHELL, B. P. The effects of heat on the testes of mammals. Animal Reproduction, v. 3, n. 2, p. 81-91, 2006. Available from: <https://goo.gl/Vw5dJz>. Viewed: 26 Feb. 2018.

SOLYMOSI, N.; TORMA, C.; KERN, A.; MARÓTIAGÓTS, Á.; BARCZA, Z.; KÖNYVES, L.; BERKE, O.; REICZIGEL, J. Changing climate in Hungary and trends in the annual number of heat stress days. International Journal of Biometeorology, v. 54, n. 4, p. 423-431, 2010. doi: 10.1016/j.livsci.2009.01.014

TEXEIRA, M.; PARUELO, J. M. Demography, population dynamics and sustainability of the Patagonian sheep flocks. Agricultural Systems, v. 87, n. 2, p. 123-146, 2006. doi: 10.1016/j.agsy.2004.11.005.

WILLIAMSON, P. The fine structure of ejaculated ram spermatozoa following scrotal heating. Journal of Reproduction and Fertility, v. 40, n. 1, p. 191-195, 1974. doi: 10.1530/jrf.0.0400191. 